\title{
EREDUKSI TINGKAT STRES KETUA EKSTRAKURIKULER DENGAN TEKNIK MINDFULNESS-BASED STRESS REDUCTION
}

\author{
Restu Afdal Ramadhan ${ }^{1}$ \\ Rochani $^{2}$ \\ Raudah Zaimah Dalimunthe ${ }^{3}$
}

\begin{abstract}
Abstrak
Penelitian ini bertujuan untuk mengetahui apakah teknik Mindfulness-Based Stress Reduction (MBSR) mampu untuk mereduksi tingkat stres yang dialami ketua ekstrakurikuler salah satu MA Negeri di Kota Serang. Populasi yang digunakan sebanyak 19 siswa ketua ekstrakurikuler dan sampel diambil sebanyak 1 siswa ketua ekstrakurikuler yang memiliki tingkat stres sangat tinggi yang dipilih dengan teknik purposive sampling. Metode penelitian yang digunakan yaitu eksperimen Single Subject Research (SSR) dengan desain A-B-A. Pengumpulan data menggunakan instrument stres Perceived Stress Scale (PSS) dengan jumlah butir 7 pernyataan valid dan nilai reliabilitas 0,779 . Hasil analisis data menggunakan dua metode yakni analisis dalam kondisi dan analisis antar kondisi, diperoleh tingkat stres dengan skor 23 kategori sangat berat turun menjadi skor 6 kategori normal. Hasil penelitian terjadi penurunan tingkat stres ketua ekstrakurikuler PMR sebesar 74\%. Kesimpulan adanya pengaruh teknik mindfulness-based reduction efektif menurunkan tingkat stres ketua ekstrakurikuler PMR di salah satu MA Negeri di Kota Serang. Penelitian dapat dilakukan lebih lanjut untuk mendukung terlaksananya program BK di sekolah.
\end{abstract}

Kata Kunci: Stres, Ketua Ekstrakurikuler, Mindfulness-Based Stres Reduction, Perceived Stress Scale, Single Subject Research, Desain A-B-A.

\section{Abstract}

This study aims to determine whether the Mindfulness-Based Stress Reduction (MBSR) technique is able to reduce the stress level experienced by the extracurricular leader of one of the state MA in Serang City. The population used was 19 extracurricular chair students and the sample was taken as much as 1 extracurricular chair student who had a very high stress level which was selected by purposive sampling technique. The research method used is the Single Subject Research (SSR) experiment with an A-B-A design. Data collection uses the Perceived Stress Scale (PSS) stress instrument with a total of 7 valid statements and a reliability value of 0.779 . The results of data analysis using two methods, namely analysis in conditions and analysis between conditions, obtained stress levels with a score of 23 very severe categories down to a score of 6 normal categories. The results of the study there was a decrease in the stress level of the PMR extracurricular leader by 74\%. The conclusion is that the influence of mindfulness-based reduction techniques is effective in reducing the stress level of the PMR extracurricular leader in one of the MA in Serang City. Further research can be carried out to support the implementation of the guidance \& counseling program in schools.

Keywords: Stress, Extracurricular Leader, Mindfulness-Based Stress Reduction, Perceived Stress Scale, Single Subject Research, A-B-A Design.

\footnotetext{
${ }^{1}$ Universitas Sultan Ageng Tirtayasa, restuafdalr@gmail.com

${ }^{2}$ Universitas Sultan Ageng Tirtayasa, hrochanie@yahoo.co.id

${ }^{3}$ Universitas Sultan Ageng Tirtayasa, raudah@untirta.ac.id
} 


\section{PENDAHULUAN}

Siswa yang mengemban amanah menjadi ketua ekstrakurikuler tentu merasakan stres. Tingkat stres yang dirasakan oleh ketua ekstrakurikuler bermacam-macam, mulai dari normal, ringan, sedang, tinggi hingga sangat tinggi. Berdasarkan hasil studi pendahuluan yang dilakukan oleh peneliti di lokasi penelitian. Sebanyak 117 responden dari 16 ekstrakurikuler, didapati bahwa siswa yang mengikuti kegiatan ekstrakurikuler sebesar $76 \%$ responden menyatakan stres dan kebingungan untuk mengatasinya. Hal tersebut dilihat dari 90 responden menyatakan tidak tahu stres, cara menangani dan menghindari dengan baik. Selain stres, sebesar 53\% responden tidak dapat menyeimbangkan waktu antara kegiatan akademik dengan kegiatan ekstrakurikuler, sebesar 91\% responden menyatakan belum memiliki keterampilan untuk memimpin. Hal tersebut sangat mendorong responden mengalami stres ketika terpilih menjadi ketua ekstrakurikuler. Sebesar $60 \%$ responden belum dapat melakukan regulasi emosi yang baik. Hal ini dikarenakan responden yang masih tahap remaja sehingga regulasi emosi belum baik ketika dihadapkan pada situasi tertentu. Selain itu, sebesar 53\% responden kelelahan secara fisik dengan kegiatan sekolah.

Data mengenai hasil studi pendahuluan peneliti didukung dengan hasil wawancara bersama koordinator salah satu sekolah MA Negeri di Kota Serang. Hasilnya menyatakan bahwa siswa sering sekali merasa stres tahap ringan sampai sedang karena kegiatan ekstrakurikuler dan akademik yang banyak meski di masa pandemi. Selain itu, banyak siswa dari kelas XI yang baru menjabat sebagai ketua ekstrakurikuler, sehingga hal tersebut dapat mengakibatkan stres sebagai bagian dari adaptasi diri terhadap amanah baru. Dengan hasil data $91 \%$ siswa belum memiliki keterampilan untuk memimpin, sangat wajar apabila siswa tersebut akan merasakan stres saat masa awal memimpin ekstrakurikuler. Selain itu, banyak siswa belum dapat melakukan manajemen waktu dengan baik, terbukti dengan tugas sekolah yang menumpuk, hal tersebut

Insight: Jurnal Bimbingan dan Konseling 10(2) dapat membuat siswa stres. Di sisi lain, banyak siswa tidak tahu cara mengatasi stres dengan baik, karena dalam pandemi Covid-19 membuat layanan dan program bimbingan dan konseling terkhusus pada konseling individu sedikit terhambat.

Salah satu upaya untuk menangani tingkat stres ketua ekstrakurikuler adalah menerapkan strategi Mindfulness-Based Stress Reductions (MBSR). Menurut (Novia, 2020) dengan menerapkan mindfulness individu yang mengalami stres dapat membangun kesadaran diri untuk lebih memperhatikan tubuh dan emosinya. Mindfulness mampu meregulasi tingkat emosi pada kesadaran paling dalam. Menurut (Zinn, 2016) dengan teknik MBSR dapat dengan sepenuhnya sadar dan mengendalikan pikiran. Teknik ini meningkatkan kemauan seseorang untuk melihat peristiwa yang membuat stres, memungkinkan dirinya dapat melihat pola pikiran dengan jelas dengan menggunakan alat indra mereka. Sementara itu, menurut (Erford, 2017) MBSR menuntut individu untuk menerima tanpa menghakimi pengalaman saat ini untuk mengembangkan toleransi dan perasaan yang sulit diekspresikan.

Teknik ini sangat cocok digunakan untuk individu yang mengalami stres karena tegangan otot dapat dilenturkan dengan yoga hatha, meditasi pernafasan dan relaksasi dapat membantu individu untuk mengontrol emosinya, sehingga individu dapat melihat dan menganalisis fikiran dan memvisualisasikannya. Seperti mengapa hal itu terjadi, apa penyebabnya dan apa solusi atas itu, dengan menekankan kesadaran diri serta afirmasi positif. Selain itu dengan melakukan bodyscanning, individu secara sadar dan fokus dapat merasakan keseluruhan pikiran, emosi dan tubuh untuk lebih menyadari penyebab stres dan berfokus pada solusi.

Praktik MBSR menggunakan 8 langkah untuk mengatasi stres. Mulai dari posisi meditasi kesadaran nafas untuk membangun perasaan rileks dalam melakukan yoga hatha, meditasi pernafasan dan bodyscanning. Kemudian dilanjutkan melihat pikiran dan perilaku serta menganalisis persepsi yang muncul. Selanjutnya, melatih perasaan dan regulasi emosi untuk 
meningkatkan kesejahteraan, mencoba untuk memberikan ruang dalam mengekspresikan emosi. Pada tahap terakhir, dibawa untuk menerima dirinya dengan menjadi sadar akan yang menyenangkan dan tidak, menumbuhkan gaya hidup yang sehat dan penerimaan diri atas perubahan. MBSR menawarkan kedamaian dan kesejahteraan pada diri (well being), membantu menghadapi dan menerima realitas kehidupan dengan lebih rileks dan menganalisis lebih jauh pikiran individu. Selain itu, pelatihan mindfulness mampu menurunkan agresivitas, kontrol diri, regulasi emosi dan hubungan interpersonal (Novia, 2020).

Perbedaan penelitian ini dengan penelitian lainnya terletak pada subjek yang digunakan dalam penelitian, yakni stres ketua ekstrakurikuler. Penelitian mengenai teknik MBSR sebelumnya hanya digunakan untuk mereduksi tingkat stres dalam organisasi, pegawai perusahaan, pasien dalam gangguan jiwa, perokok, kecemasan remaja sampai mahasiswa.

Adapun tujuan dari penelitian ini adalah untuk melihat profil tingkat stres ketua ekstrarikuler MA Negeri di Kota Serang dan untuk mengetahui efektifitas teknik MBSR guna mereduksi tingkat stres ketua ekstrakurikuler MA Negeri di Kota Serang Tahun 2021.

\section{KAJIAN TEORITIK}

\section{Ekstrakurikuler}

Kegiatan ekstrakurikuler merupakan sebuah wadah pengembangan potensi siswa, penguatan pendidikan karakter dan pengembangan profil pelajar Pancasila yaitu: kebhinekaan global, bernalar kritis, mandiri, bertaqwa kepada Tuhan dan berakhlak mulia. Hal ini sesuai dengan Peraturan Menteri Pendidikan Dan Kebudayaan Republik Indonesia (Salinan) (2014) pasal 1 ayat 2 dan pasal 3 ayat 2 bahwa setiap satuan pendidikan berkewajiban untuk menyelenggarakan kegiatan ekstrakurikuler secara sistematis dan terpola. Unit pendidikan dapat mengadakan kegiatan ekstrakurikuler sesuai dengan kebutuhan.

Menurut (Pratiwi, 2020), kegiatan

ekstrakurikuler lebih diarahkan untuk membentuk kepribadian siswa, dengan mengembangkan aspek tertentu dari apa yang tidak ditemukan pada kurikulum. Melalui kegiatan ekstrakurikuler, pendidik dapat mengelola pembinaan siswa dengan orientasi pada pembinaan akhlak mulia, sehingga memberikan dampak positif, baik dalam hubungan transendental, guru, orang tua dan teman serta diri sendiri (Prayoga, 2019, p. 94). Hal ini sejalan dengan tujuan dari pendidikan nasional dan pelajar Pancasila, yaitu siswa yang berakhlak mulia dan dapat mengimplementasikan ilmu pada kehidupan sehari hari terutama dalam kegiatan ekstrakurikuler, sehingga siswa tidak melakukan penyimpangan dan dapat memfokuskan diri pada pengembangan potensi Unwanullah dan Zuchdi dalam (Prayoga, 2019)

Jenis ekstrakurikuler sendiri terbagi menjadi 3, yakni; (1) ekstrakurikuler wajib adalah ekstrakurikuler yang diadakan oleh satuan pendidikan dan wajib diikuti oleh seluruh peserta didik; (2) ekstrakurikuler pilihan adalah ekstrakurikuler yang dikembangkan oleh masing-masing unit pendidikan sesuai dengan sumber daya sarana dan prasarana. Siswa dapat mengikuti ekstrakurikuler pilihan sesuai minat dan bakatnya. Selain itu, fungsi ekstrakurikuler sendiri menurut Undang - Undang (UU) Sistem Pendidikan Nasional pasal 4 (2003) dan Peraturan Menteri Pendidikan Nasional Republik Indonesia pasal 4 ayat 1 (2008) adalah pengembangan kreatifitas agar siswa merasa senang saat mengembangkan bakatnya, pengembangan sosial, sarana rekreatif dan persiapan karir guna menentukan karir kedepan (Rosida \& Arifiin, 2020, p. 248).

Adapun peran ekstrakurikuler yakni memperdalam, memperluas, memperkaya dan memperbaiki pengetahuan siswa, melengkapi upaya pembinaan dan pembentukan kepribadian dan meningkatkan bakat, minat yang memacu pada kemampuan mandiri, percaya diri, kreatif dan kecakapan hidup (life skill) (Narmoatmojo, 2010). Selain itu, kelebihan ekstrakurikuler diantaranya; (a) membentuk karakter yang bertaqwa dan berakhlak; (b) membentuk jiwa disiplin dan bertanggung jawab; (c) lebih mengembangkan bakat minat; (d) melatih kognitif, afektif dan psikomotor siswa; (e) pengembangan diri, manajemen waktu dan 
fleksibilitas; dan (f) memiliki karakter sosial yakni relasi sosial dan rasa empati. Kekurangan ekstrakurikuler yakni; (a) kelelahan secara fisik dan psikologis; (b) stres karena beban dan sering merasa kewalahan; (c) sakit karena kelelahan fisik dan sedikit istirahat; (d) manajemen waktu yang buruk dan akademik yang terbengkalai karena siswa tidak dapat memfokuskan diri pada satu hal (Saputri et al., 2020).

\section{Masa Remaja}

Menurut (Hurlock, 1980) istilah adolescence meliputi kematangan mental, emosional, sosial, fisik dan religious sehingga individu menjadi utuh secara keseluruhan Pearls dalam (Yustiana et al., 2017). (Hurlock, 1980) juga menyatakan pada masa ini, remaja harusnya mampu mengintegrasikan dirinya ke masyarakat, memiliki hubungan sosial dan intelektual yang lebih besar. Oleh karena itu, tahap penyesuaian sikap dan perilaku yang ditunjukan oleh usia remaja sangat penting karena tuntutan sosial yang ada. Pada masa remaja terdapat empat perubahan yang terjadi, yaitu; (a) meningginya emosi karena intensitasnya bergantung pada kondisi fisik dan psikologis; (b) perubahan fisik, minat sosial dan peran, perubahan fisik selalu dianggap sebagai masalah, namun remaja akan menyelesaikan masalahnya sesuai dengan kepuasan dirinya; (c) perubahan pola perilaku, remaja mulai dapat menentukan skala prioritas sendiri; (d) remaja bersikap ambivalen, yaitu selalu takut dan ragu ketika harus bertanggung jawab atas pilihan mereka sendiri, oleh karena itu remaja sering ambigu ketika memilih suatu keputusan.

Menurut pendapat (Stein, 2020) ketika ego sudah mencapai tahap otonomi, maka munculah kehendak atas kesadaran, terbitlah kebebasan pribadi sebagai realitas subjektif. Remaja memiliki ilusi bahwa mereka memiliki kendali atas diri dan kehendak bebas yang besar. Oleh karena itu remaja mulai menentukan identitas ego sesuai dengan kelompok yang cocok untuknya (search for self identity). Lingkungan pergaulan membentuk remaja untuk menentukan identitas egonya sendiri. (Hurlock, 1980) menyatakan remaja mencari identitas diri terkait peran yang akan dilaluinya nanti, secara keseluruhan apakah dirinya akan berhasil atau

Insight: Jurnal Bimbingan dan Konseling 10(2) gagal. Remaja cenderung menjadikan idola mereka sebagai pembimbing ideal mereka dalam mencari identitas diri. Oleh karena itu, remaja selalu bersikap ambivalen, yaitu mudah terombang-ambing oleh munculnya (a) kekecewaan dan penderitaan; (b) meningkatnya konflik, pertentangan dan krisis adaptasi; (c) impian dan fantasi; (d) percintaan dan (e) keterasingan dari kehidupan dewasa dan norma kebudayaan (John, 2012).

Adapun aspek psikologis remaja terdiri dari 4 aspek yakni; (a) aspek psikososial yaitu remaja mampu untuk mengintegrasikan dirinya kedalam masyarakat, memiliki hubungan sosial dan intelektual yang lebih besar. Pada tahap ini remaja mengalami krisis indentitas, self esteem rendah sehingga berusaha mencari role model yang akan dijadikan panutan. Pengaruh lingkungan teman sebaya sangat besar terhadap perkembangan psikososial karena tempat remaja mencari identitas diri (Hurlock, 1980); (b) aspek kognitif yaitu remaja memasuki tahap operasional formal yakni memiliki kemampuan berfikir, memecahkan masalah, bernalar kritis, berpikir abstrak dan logis rasional. Menurut (John, 2012) perkembangan kognitif remaja diperoleh dari bimbingan individu yang terlatih dalam menggunakan alat dan budayanya. Lingkungan sosial, orang tua, teman sebaya, komunitas pendidikan dan teknologi berpengaruh dalam pemikiran dan cara berpikir remaja; (c) aspek emosional yakni pada masa remaja, amarah cenderung meledak-ledak dengan berteriak dan mengkritik orang lain (Hurlock, 1980). Oleh karena itu remaja membutuhkan jalan keluar konstruktif untuk meredakan ketegangan tersebut. Kematangan emosi remaja tergantung dari proses pencarian jati dirinya yang terlihat ketika remaja mampu menganalisis situasi dengan kritis sebelum bereaksi secara emosional, remaja mulai mengabaikan banyak rangsangan emosi yang menimbulkan ledakan emosional; (d) aspek fisik yakni perubahan fisik yang pesat membuat sebagian remaja sedikit merasa tidak puas. Hanya sedikit remaja yang mengalami kateksistubuh atau merasa puas dengan tubuhnya. Hal ini mendorong remaja memiliki konsep diri yang kurang baik dan kurangnya harga diri selama masa remaja bahkan sampai masa dewasa. 
Kesadaran adanya reaksi sosial atas bentuk tubuh menyebabkan remaja khawatir tidak sesuai dengan standar budaya yang berlaku. Kesadaran ini timbul karena daya tarik fisik berperan penting dalam hubungan sosial dan memilih pemimpin. Oleh karena itu, remaja mencoba untuk memperbaiki penampilan dengan cara berolahraga, melakukan perawatan wajah dan lainnya (Hurlock, 1980).

\section{Stres}

Stres adalah respon tubuh terhadap tekanan, timbulnya stres karena individu dan lingkungan bertransaksi nyata atau tidak (Segarahayu, 2016, p. 3). Selain itu stres diartikan sebagai tekanan individu dalam usaha mencapai target standar pemenuhan hidup karena adanya ketidakseimbangan antara tuntutan dan kemampuan diri (Nisrina, 2016). Menurut (Gaol, 2016) stres yang jumlahnya begitu banyak dapat membahayakan kondisi fisik dan mental setiap orang, apabila stres individu tidak ditangani dan dikelola dengan baik, maka akan memberikan efek jangka panjang dan berdampak pada timbulnya penyakit, gangguan somatik, gangguan kesehatan seperti lelah, sakit kepala, mudah lupa, bingung, kehilangan gairah seksual dan tekanan darah tinggi (Musradinur, 2016).

Seringkali individu tidak merasakan gejala stres, karena individu masih dalam tahap stres baik (eustres). Individu akan menyadari dirinya stres ketika mencapai tahap stres buruk (distress) dan mengakibatkan tidak terkontrolnya emosi, koginitif, fisik dan perilaku (Era, 2019). Sayangnya individu terkadang akan menyangkal (denial) bahwa dirinya sedang mengalami stres (Hawari dalam Ariyanto, 2016). Model stres terdiri dari 3, yaitu; (a) stres model stimulus adalah model yang berfokus bahwa lingkungan menjadi sebab munculnya stresor (Musradinur, 2016). Model ini berkembang saat prajurit militer sedang berperang perang yang dianggap sebagai penyebab stres, cemas dan memburuknya kesehatan karena stimulus lingkungan atau kondisi perang tersebut (Gaol, 2016); (b) stres model respon menekankan bahwa stres adalah hasil reaksi atau respon tubuh terhadap stres sebagai stimulusnya. Model stres ini memiliki dua komponen yaitu respon

Insight: Jurnal Bimbingan dan Konseling 10(2) psikologis dan respon fisiologis yang disebut dengan strain atau ketegangan (Musradinur, 2016). Hal ini terjadi bersamaan ketika individu mengalami stres dan kecemasan berlebih yang mempengaruhi kinerja otak sehingga muncul reaksi tubuh terhadap stres; (c) stres model transaksional berfokus pada respon emosi dan kognitif yang didasarkan pada interaksi manusia dengan lingkungan. Interaksi tersebut saling mempengaruhi dan disebut dengan hubungan transaksional (Musradinur, 2016). Model stres ini individu juga merupakan perantara yang aktif, yang dapat mempengaruhi stresor melalui strategi perilaku kognitif dan emosional. Ketika individu berhadapan dengan tekanan dan stres maka akan melakukan appraisal (penilaian) dan coping (penanggulangan) (Gaol, 2016).

Tahapan stres itu sendiri sudah dirangkum oleh Robert Van Amberg menjadi 8 tahap stres (1979). Selain itu terdapat 3 fase stres, yakni; (a) reaksi alarm sebagai tanda tubuh akan mengalami stres; (b) resistensi (perlawanan) individu beradaptasi dan bertahan terhadap stres; (c) exhaustion (kelelahan) ketika tubuh tidak kuat untuk melawan lagi dan mengalami distress. Dampak stres tidak selalu buruk, apabila tekanan berdampak positif maka akan menjadi eustress yang memberikan motivasi dan kinerja lebih baik. Namun stres juga dapat berdampak negatif (distress) karena individu sudah lelah sehingga motivasi dan kinerja semakin menurun sehingga menimbulkan berbagai gangguan (Purnomolastu, 2024).

\section{Mindfulness-Based Stress Reduction (MBSR)}

Dewasa ini MBSR semakin banyak digunakan (Passmore, 2019). Karena teknik ini melatih atensi diri untuk fokus pada keadaan saat ini lalu menerima diri tanpa penialian apapun, terhadap orang lain, masyarakat komunitas atau hidup secara keseluruhan (Alberth, 2006). Sehingga individu terhindar dari mindlessness yakni menolak realitas pikiran dan emosi kemudian lari dari permasalahan (Waskito, n.d). Lebih lanjut, (Baniasadi et al., 2014) dengan teknik MBSR dapat meningkatkan kesejahteraan individu, ketenangan psikologis dan kesejahteraan emosional, karena individu diajak untuk menerima (acceptance) dan 
penerimaan tanpa syarat (unconditional positive regard) ketika proses konseling (Gantina et al., 2018).

Teknik MBSR dikembangkan oleh John Kabat-Zinn di Center for Mindfulness, University of Massachusets Medical School pada tahun 1970-an. Intervensi MBSR adalah terapi yang berasal dari meditasi kuno filosofi spiritual Buddhisme dan yoga sekuler yang sudah ada lebih dari 2.600 tahun. Meditasi spiritual Buddhisme adalah sikap dan metode untuk mengurangi penderitaan pribadi dan mengembangkan welas asih (self compassion) diri sendiri dan manusia secara (Janssen et al., 2018). John Kabat-Zinn membawa metode spiritual Buddhis timur yang digabungkan dengan metode penelitian empiris barat dan menghasilkan MBSR (Siegel dalam Waskito, n.d). Selama meditasi kesadaran, konsentrasi difokuskan saat duduk atau pada indra, suara atau sensasi udara. Tujuan akhir dari teknik ini adalah individu mencapai kondisi self awareness, attention, self acceptance sehingga dapat mencapai individual mindfulness dan individual wisdom (King \& Badham, 2018, p. 6).

Menurut (Alberth, 2006) MBSR mengajarkan individu untuk memperhatikan pemikiran, mengamati dan menganalisisnya agar dapat diarahkan pada perasaan dan perilaku yang sehat. Membawa individu untuk melihat peristiwa yang membuat stres saat ini sebagai tantangan untuk mengembangkan diri, bukan sebuah ancaman (Zinn, 2016). Teknik MBSR berfungsi untuk melihat jelas pola sehat dan berbahaya dari fikiran tersebut. Dengan cara ini kita akan lepas dari pola fikiran yang negatif serta mendorong individu mencapai kesejahteraan diri (Ahern, 2017, p. 1). Teknik MBSR memiliki tujuh sikap yang membantu individu untuk mengurangi kecemasan dan depresi secara signifikan, yakni; (a) nonjudgment; (b) kesabaran; (c) pikiran seorang pemula; (d) kepercayaan; (e) tidak berjuang; (f) penerimaan; (g) melepaskan (Alberth, 2006) \& (Zinn, 2016).

Intervensi MBSR adalah program delapan minggu dimana peserta bertemu selama 1-2 jam persesi setiap minggu. Intervensi MBSR dibagi menjadi praktik formal yaitu selama enam minggu, 45 menit perminggu dan praktik informal dua minggu selama 45 menit perminggu (Shankland, Tessier, Gauchet, Celine Baeyens, \& Strub, 2020). Dalam praktik informal individu diminta untuk berlatih meditasi mandiri diluar sesi konseling dengan meditasi duduk, meditasi jalan kaki dan yoga hatha yang lembut selama 30 menit (Evans et al., 2018). Melalui praktik MBSR, individu memiliki sikap "mindfull". Kesadaran dibangun karena praktik formal dan informal yang membuat individu memiliki tujuh sifat karakter mindfulness (Alberth, 2006) \& (Zinn, 2016).

Jalan mindfulness adalah secara sadar menerima diri dan apa yang terjadi kepada diri, meskipun itu menyakitkan, dampak positif teknik MBSR, yakni; (a) individu memiliki hubungan positif, rasa percaya diri, optimisme, ketenangan yang tinggi dan santai; (b) individu menyadari secara penuh efek negatif kecemasan, stres dan gangguan psikosomatis; (c) meningkatkan kesejahteraan individu dan kebahagian dalam kepuasan hidup; (d) individu mampu mengendalikan perubahan positif fisik dan kesehatan mental serta mereduksi pikiran negatif; (e) meningkatkan kesadaran dan penerimaan diri sehingga meningkatkan rasa welas asih (compassion), selain itu individu mengembangkan kognitif dan regulasi emosi ketika stres (Waskito, n.d).

\section{METODE PENELITIAN}

Metode penelitian yang digunakan adalah eksperimen single subject research (SSR). Penelitian ini menggunakan desain penelitian AB-A dengan menggunakan tiga fase pengukuran yang di ulang-ulang. Pada fase baseline A1 dilakukan uji kondisi sebanyak 3 kali untuk melihat kondisi subjek secara natural sebelum diberikan intervensi, fase intervensi dilakukan uji kondisi sesuai dengan teknik yang dipakai dan fase baseline A2 dilakukan sebanyak 3 kali sebagai bentuk follow up dan mengukur tingkat stabilitas modifikasi.

Penelitian ini dilakukan di salah satu MA Negeri di Kota Serang, waktu penelitian yang dimulai pada bulan Maret-November 2021. Populasi ditujukkan kepada seluruh ketua ekstrakurikuler sebanyak 19 responden sebagai uji ke-1 fase baseline A1. Sampel pada penelitian ini sebanyak 1 ketua ekstrakurikuler 
dengan tingkat stres paling tinggi, pengambilan sampel dilakukan dengan menggunakan teknik purposive sampling. Instrumen yang digunakan yaitu Perceived Stress Scale (PSS). Teknik pengumpulan data menggunakan wawancara terstruktur dan angket yang sudah divalidasi oleh ahli. Teknik analisis data yang digunakan dalam penelitian SSR adalah analisis dalam kondisi dan analisis antar kondisi.

\section{HASIL PENELITIAN}

Penelitian ini dilakukan untuk melihat pengaruh teknik mindfulness-based stress reduction untuk mereduksi tingkat stres ketua ekstrakurikuler. Penelitian dilakukan dengan eksperimen SSR desain A-B-A. Pada fase baseline A1 dilakukan uji sebanyak 3 kali, pada fase intervensi (B) sebanyak 8 kali sesuai dengan teknik MBSR, terakhir fase baseline A2 dilakukan uji sebanyak 3 kali.

Dari angket instrument PSS yang disebar ke 19 ketua ekstrakurikuler, pada uji ke-1 fase baseline A1 didapati profil tingkat stres ketua ekstrakurikuler sebanyak 7 ketua ekstrakurikuler memiliki kategori stres Sangat Berat dengan persentase $37 \%, \quad 10$ ketua ekstrakurikuler memiliki kategori Berat dengan persentase 53\%, 1 ketua ekstrakurikuler memiliki kategori Sedang dengan persentase $5 \%$ dan 1 ketua ekstrakurikuler memiliki kategori Ringan dengan persentase 5\%. Skor tertinggi diraih oleh ketua ekstrakurikuler PMR dengan nilai 23 kategori Sangat Berat dan skor terendah diraih oleh ketua ekstrakurikuler Paduan Suara dengan nilai 8 kategori Ringan.

Selanjutnya, peneliti hanya memilih 1 sampel dengan nilai stres paling tinggi yaitu ketua ekstrakurikuler PMR untuk dilanjutkan uji fase baseline A1 selanjutnya. Pada uji ke-2 fase baseline A1 didapati skor 22 kategori Sangat Berat dan terakhir uji ke-3 fase baseline A2 didapati skor 24 kategori Sangat Berat. Selanjutnya memasuki fase intervensi (B) selama 8 kali sesi konseling MBSR, peneliti melakukan uji tiap sesi untuk melihat penurunan tingkat stres. Pada sesi ke-1 fase intervensi (B) didapati data sebesar 22, sesi ke-2 data sebesar 20 , sesi ke-3 sebesar 17 , sesi ke-4 sebesar 15 , sesi ke-5 sebesar 12, sesi ke-6 sebesar 14, sesi ke-7 sebesar 11 dan terakhir sesi ke-8 sebesar
11. Setelah fase intervensi, selanjutnya memasuki uji fase baseline dilakukan sebanyak 3 kali. Pada uji ke-1 fase baseline A2 skor sebesar 9 kategori Ringan, uji ke-2 skor sebesar 8 kategori Ringan dan uji ke-3 skor sebesar 6 kategori Normal.

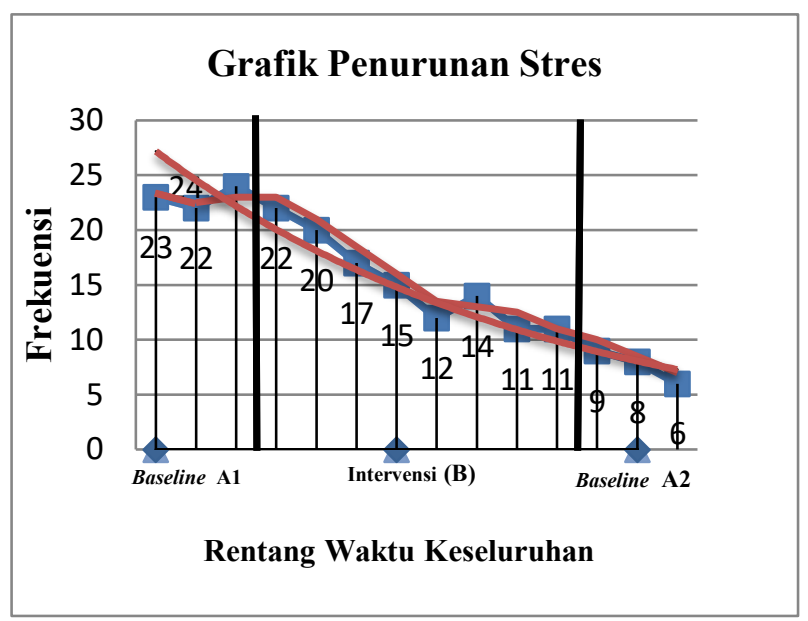

Grafik 1. Trend Penurunan Tingkat Stres

Penelitian ini menggunakan analisis dalam kondisi dan analisis antar kondisi.

\begin{tabular}{|c|c|c|c|}
\hline Kondisi & A1 & B & A2 \\
\hline Panjang Kondisi & 3 & 8 & 3 \\
\hline $\begin{array}{l}\text { Estimasi } \\
\text { Kecenderungan } \\
\text { Arah }\end{array}$ & & & \\
\hline $\begin{array}{l}\text { Kecenderungan } \\
\text { Stabilitas (Trend } \\
\text { Stability) }\end{array}$ & $\begin{array}{l}\text { Stabil } \\
100 \%\end{array}$ & $\begin{array}{c}\text { Stabil } \\
37,5 \%\end{array}$ & $\begin{array}{c}\text { Stabil } \\
33 \%\end{array}$ \\
\hline Jejak Data & $(=)$ & $(+)$ & $(+)$ \\
\hline $\begin{array}{l}\text { Level Stabilitas } \\
\text { dan Rentang }\end{array}$ & $\begin{array}{l}\text { Stabil } \\
22-24\end{array}$ & $\begin{array}{l}\text { Stabil } \\
13-17\end{array}$ & $\begin{array}{c}\text { Stabil } \\
7-8\end{array}$ \\
\hline Perubahan Level & $\begin{array}{l}24-22 \\
(+2 \%)\end{array}$ & $\begin{array}{c}22-11 \\
(+12 \% \\
) \\
\end{array}$ & $\begin{array}{c}9-6 \\
(+2 \%)\end{array}$ \\
\hline
\end{tabular}

Tabel 1. Analisis Dalam Kondisi

Hasil Analisis Dalam Kondisi diatas diketahui bahwa panjang kondisi yaitu banyaknya data atau skor pada setiap kondisi tergantung dari panjangnya intervensi yang 
diberikan. Dalam penelitian ini diperoleh panjang kondisi fase baseline $\mathrm{A} 1=3$, intervensi (B) $=8$ dan baseline $\mathrm{A} 2=3$. Selanjutnya, estimasi kecenderungan arah dapat dilihat dengan metode split middle yakni mengamati secara langsung trend data pada suatu kondisi lalu menarik garis menjadi 3 bagian sesuai dengan desain yang dipakai, bagian baseline A1 menunjukkan estimasi kecenderungan arah meningkat, bagian kedua intervensi (B) yang menunjukkan estimasi arah menurun dan bagian ketiga yakni baseline A2 yang menunjukkan estimasi kecenderungan arah semakin menurun. Selanjutnya, kecederungan stabilitas (trend stability) dilihat konsistensi nilai pada sebelum intervensi dan setelah intervensi. Diperoleh bahwa data baseline A1 memiliki kecenderungan stabilitas $100 \%$, setelah memasuki fase intervensi (B) data yang diperoleh sebesar 37,5\% dan setelah memasuki kondisi baseline A2 data yang diperoleh 33\%. Sehingga dapat disimpulkan bahwa terjadi penurunan tingkat stres secara stabil sebesar $67 \%$, hal ini dikarenakan adanya latihan pernafasan, latihan yogha hatha dan meditasi tubuh yang membantu konseli merasa rileks, selain itu terjadi pengungkapan pikiran kreatif, pengekspresian serta regulasi emosi, pemberian tugas rumah juga berpengaruh dalam melakukan refleksi setelah sesi konseling. Selanjutnya jejak data dalam baseline A1 tidak ada perubahan data, kemudian intervensi (B) terjadi perubahan yang membaik dengan adanya penurunan tingkat stres secara signifikan sampai dengan baseline A2. Selanjutnya level stabilitas dan rentang dikatakan stabil karena nilai batas bawah dan batas atas hasilnya rendah. Terakhir perubahan level terjadi penurunan yang signifikan baseline A1 sebanyak 2, fase intervensi sebanyak 12 dan fase baseline A2 sebanyak 3 .

\begin{tabular}{|c|c|c|}
\hline No & $\begin{array}{c}\text { Perbandingan } \\
\text { Kondisi }\end{array}$ & $\begin{array}{c}\text { A:B } \\
(2: 1)\end{array}$ \\
\hline 1 & $\begin{array}{c}\text { Jumlah variabel yang } \\
\text { diubah }\end{array}$ & 1 \\
\hline 2 & $\begin{array}{c}\text { Perubahan } \\
\text { kecenderungan arah }\end{array}$ & $\underset{(=)}{(+)} \underset{(+)}{\checkmark}$ \\
\hline
\end{tabular}

\begin{tabular}{|c|c|c|}
\hline 3 & $\begin{array}{c}\text { Perubahan } \\
\text { kecenderungan } \\
\text { stabilitas }\end{array}$ & $\begin{array}{c}\text { Stabil ke } \\
\text { Stabil }\end{array}$ \\
\hline 4 & $\begin{array}{c}\text { Perubahan level (mean } \\
\text { baseline A1 ke batas } \\
\text { bawah baseline A2) }\end{array}$ & $\begin{array}{c}23-7 \\
(+) 16\end{array}$ \\
\hline 5 & Presentase Overlap & $\begin{array}{c}\mathrm{V}=\frac{0}{14} \times 100 \% \\
=0 \%\end{array}$ \\
\hline
\end{tabular}

Tabel 2. Analisis Antar Kondisi

Hasil Analisis Antar Kondisi harus memperhatikan komponen yang akan dianalisis meliputi jumlah variabel yang diubah yakni berjumlah 1, perubahan kecenderungan arah yakni menurun, perubahan kecenderungan stabilitas yakni dari stabil ke stabil, perubahan level sebesar 16 dan presentase data yang tumpang tindih (overlap) sebesar $0 \%$.

Hasil penelitian ini menunjukkan semakin kecil presentase overlap, maka semakin baik pengaruh intervensi terhadap target behavior begitupun sebaliknya. Pada penelitian ini persentase overlap sebesar $0 \%$ yang artinya teknik MBSR berpengaruh untuk mereduksi tingkat stres ketua ekstrakurikuler di salah satu MA Negeri di Kota Serang. Pencapaian skor overlap yang rendah memperkuat hipotesis bahwa teknik MBSR sangat efektif untuk menurunkan tingkat stres yang dialami ketua ekstrakurikuler.

\section{KESIMPULAN}

Berdasarkan penelitian yang telah dilakukan, diperoleh hasil bahwa ketua ekstrakurikuler mengalami penurunan tingkat stres dari berat hingga normal dengan menggunakan teknik Mindfulness-Based Stress Reduction. Hasil penelitian menunjukkan nilai overlap pada antar kondisi dalam penelitian sebesar 0\%. Pencapaian skor overlap yang rendah memperkuat hipotesis yang menyatakan bahwa teknik MBSR mampu menurunkan tingkat stres ketua ekstrakurikuler di salah satu MA Negeri di Kota Serang tahun 2021. Penurunan tingkat stres ketua ekstrakurikuler 
digambarkan dengan Hasil data gain pada tahap kondisi ke-1 fase baseline A1 diperoleh skor 23 kemudian fase baseline A2 diperoleh skor 9, terjadi penurunan tingkat stres dengan selisih beda skor 14 dengan persentase $61 \%$. Tahap kondisi ke-2 fase baseline A2 diperoleh skor 22 kemudian fase baseline A2 diperoleh skor 8, terjadi penurunan tingkat stres dengan selisih beda skor 14 dengan persentase $61 \%$. Terakhir tahap kondisi ke-3 fase baseline A2 diperoleh skor 24 kemudian fase baseline A2 diperoleh skor 6 , terjadi penurunan tingkat stres dengan selisih beda skor 18 dengan persentase $75 \%$.

\section{Saran}

Berdasarkan hasil penelitian diatas terdadapat beberapa saran sebagai berikut:

Penelitian ini dapat dilanjutkan dengan membuat media baik berbentuk website, komik, aplikasi dll. Selanjutnya, pada fase baseline penelitian dapat dilakukan sebanyak 5 kali agar stabilitas data terjamin. Selain itu, dapat menggunakan konseling kelompok dengan teknik yang sama agar mampu mencapai subjek penelitian yang lebih besar dan menggunakan subjek penelitian di jenjang SMP atau Perguruan Tinggi. Penelitian ini dapat digunakan sebagai bahan referensi terkhusus bagi yang menggunakan teknik mindfullnes dalam pelaksanaan teknik konseling. Selain itu, metodologi penelitian single subject research yang digunakan dapat dijadikan sebagai bahan acuan untuk melakukan penelitian serupa dengan desain penelitian yang berbeda.

Terakhir, sekolah dapat membuat rencana program bimbingan dan konseling yang dapat mereduksi tingkat stress, tekanan, cemas bahkan depresi pada siswa. Sehingga fungsi ekstrakurikuler mampu membantu mengembangkan siswa ke tahap optimal. Selain itu, mengingat penggunaan teknik MBSR sangat jarang digunakan dalam layanan konseling di sekolah, maka dengan adanya penelitian ini dapat dijadikan panduan untuk melakukan layanan konseling berbasis mindfulness untuk mereduksi berbagai permasalahan siswa dikemudian hari. Selain itu, agar dapat memaksimalkan potensi siswa dapat dilakukan sesi konseling menggunakan teknik ini untuk ketua ekstrakurikuler ataupun OSIS.

Insight: Jurnal Bimbingan dan Konseling 10(2)

\section{DAFTAR PUSTAKA}

Ahern, H. M. (2017). Mindfulness Based Stress Reduction Handbook. U\&Counseling.

Alberth, E. (2006). Rational Emotif Behaviour Therapy and The Mindfulness-Based Stress Reduction Training Of John KabatZin. Journal of Rational-Emotive and Cognitive-Behaviour Therapy, 63-78.

Ariyanto, E. A. (2016). Tingkat Stres Pada Remaja di Lapas Anak Blitar. Jurnal Psikologi Indonesia, 226-231.

Baniasadi, H., Kashani, F. L., \& Jamshidfar, Z. (2014). Effectivenest Of Mindfulness Training On Reducting Of Distress Of Patiens Infected By Breast Cancer. Elsevier: Procedia Social and Behaviours Sciences, 994-948.

Era, F. (2019). How To Deal With Stres. Psikologi Corner.

Erford, B. t. (2017). 40 Teknik Yang Harus Diketahui Oleh Konselor.

Evans, S., Wyka, K., \& Blaha, K. T. (2018). Compassion Mediated Well-Being Improvements In And MBSR Program In A Comunity Based Sample. Springer Sciences, 1-8.

Gaol, N. T. L. (2016). Teori Stres: Stimulus, Respon, dan Transaksional. Jurnal Bulletin Psikologi, 1-11.

Hurlock, B. E. (1980). Development Psychology: Life Span Approach, 15 Edition. MC Graw-Hil Education INC.

Peraturan Menteri Pendidikan dan Kebudayaan Republik Indonesia (Salinan), Pub. L. No. Pasal 1 Ayat 2, Pasal 3 Ayat 2, 1 (2014).

Janssen, M., Heerkens, Y., \& Kuijer, W. (2018). The Effect Of MBSR On Employe Mental Health An Over View. Plos One, 1-37.

John, W. S. (2012). Life Span Development 13'Edition: Perkembangan Masa Hidup Jilid 1. Erlangga.

King, E., \& Badham, R. (2018). The Whell Of Mindfulness: Kerangka Generatif untuk Kepemimpinan Mindful Generasi Kedua. Spingers Science, 1-11.

Komalasari, G., Wahyuni, E., \& Karsih. (2016). Teori dan Teknik Konseling. Indeks.

Musradinur. (2016). Stres dan Cara 
Mengatasinya Dalam Perspektif Psikologi. Jurnal Edukasi, 183-199.

Narmoatmojo, W. (2010). Makalah Ekstrakurikuler di Sekolah: Dasar Kebijakan dan Aktualisasinya. Jurnal UNS, 14.

Peraturan Menteri Pendidikan Nasional Republik Indonesia, Pub. L. No. 4 Ayat 1, 1 (2008).

Nisrina, G. E. (2016). Perbedaan Strategi Coping Stres Pada Mahasiswa Organisasi dan Non Organisasi di Universitas Negeri Maulana Malik Ibrahim Malang. Jurnal Fakultas Psikologi UIN Maulana Malik Ibrahim, 165.

Novia, A. Y. (2020). Pengembangan Media Video Tutorial mengenai MindfulnessBreathing Meditation untuk Mengurangi Stres Pada Peserta Didik di SMA Negeri 58 Jakarta. Insight BK UNJ.

Passmore, J. (2019). Mindfulness Dalam Organisasi Bagian 2: Panduan Praktik untuk Menerapkan Pendekatan Berbasis Mindfulness dalam Pengembangan Kepemimpinan, Kesejahteraan dan Pembinaan. CentAURE Reading University, 1-16.

Undang - Undang (UU) Sistem Pendidikan Nasioal, Pub. L. No. 4 (2003).

Pratiwi, S. I. (2020). Pengaruh Ekstrakurikuler Pramuka Terhadap Karakter Disiplin Siswa SD. Jurnal Edukatif: Jurnal Ilmu Pendidikan, 62-70.

Prayoga, A. (2019). Manajemen Program Pembinaan Ahlak Karimah Peserta Didik melalui Ekstrakurikuler. Jurnal Islami Education Manajemen, 93-104.

Purnomolastu, N. (2024). Analisis Tingkgatan Stres dan Pengaruhnya Terhadap Kinerja Pimpinan Cabang Bank Swasta Nasional di Surabaya. Manajemen Dan Bisnis, 31-48.

Rosida, N., \& Arifiin, Z. (2020). Korelasi ANtara Ekstrakurikuler dengan Pengembangan Potensi Santri Puteri AlMahrusiyah Kediri Jawa Timur. Jurnal Ilmiah DIDDAKTIK, 238-250.

Saputri, Lilis, Syahputra, \& Setia, D. (2020). Dampak Kegiatan Ekstrakurikuler terhadap Pembentukan Karakter Siswa SMA Negeri 1 Berandan Barat. Jurnal Serunai
Matematika, 69-75.

Segarahayu, R. D. (2016). Pengaruh Manajemen Stress terhadap Penurunan Tingkat Stres pada Narapidana di LPW Malang. Artikel Psikologi, 1-16.

Stein, M. (2020). Jung's Map Of The Soul: An Introduction. Shira Media.

Waskito, P. (n.d.). Mindfulness dalam Layanan Bimbingan dan Konseling Bagi Peserta Didik Remaja di SMP. Jurnal Konvensi Nasional XXI ABKIN, 115-121.

Yustiana, Y. R., Komalasari, G., \& Fitri, S. (2017). Modul Pengembangan Keprofesian Berkelanjutan Bimbingan dan Konseling SMA. Kementrian Pendidikan dan Kebudayaan PPPPTK Penjas dan BK.

Zinn, J. K. (2016). Handbook Mindfulness Based Stress Reduction Program. 


\section{LAMPIRAN}

\section{KUISIONER PERCEIVED STRESS SCALE (PSS)}

Nama Lengkap :

Tempat, Tanggal Lahir :

Alamat

Kelas

Ketua Ekstrakurikuler

\section{Petunjuk Pengisian !!!}

Kuisioner ini berisi pertanyaan berkaitan dengan perasaan dan pikiran saudara sekalian dalam satu bulan terakhir. Terdapat lima pilihan jawaban yang disediakan.

Tidak ada jawaban benar atau salah. Semua jawaban dianggap baik dan benar.

Pilihlah jawaban yang paling sesuai dengan keadaan anda, dengan memberikan tanda ceklist ( $\sqrt{ }$ ) pada kolom disebelah kanan sesuai dengan kenyataan yang sebenar-benarnya, dengan pilihan:

$$
\begin{array}{ll}
0 & =\text { Tidak Pernah } \\
1 & =\text { Hampir Tidak Pernah } \\
2 & =\text { Kadang-Kadang } \\
3 & =\text { Hampir Sering } \\
4 & =\text { Sangat Sering }
\end{array}
$$

\begin{tabular}{|c|c|c|c|c|c|c|}
\hline \multirow{2}{*}{ No } & \multirow{2}{*}{ Pernyataan } & \multicolumn{5}{|c|}{ Jawaban } \\
\hline & & $\mathbf{0}$ & 1 & 2 & 3 & 4 \\
\hline 1 & $\begin{array}{l}\text { Pada satu bulan terakhir, seberapa sering kamu menyalahkan diri sendiri } \\
\text { selama menjadi ketua ekstrakurikuler }\end{array}$ & & & & & \\
\hline 2 & $\begin{array}{l}\text { Pada satu bulan terakhir, seberapa sering kamu merasa bersemangat setiap kali } \\
\text { melakukan kegiatan ekstrakurikuler. }\end{array}$ & & & & & \\
\hline 3 & $\begin{array}{l}\text { Pada satu bulan terakhir, seberapa sering kamu sebagai ketua merasa panik } \\
\text { ketika dihadapkan pada situasi genting yang terjadi dalam ekstrakurikuler. }\end{array}$ & & & & & \\
\hline 4 & $\begin{array}{l}\text { Pada satu bulan terakhir, seberapa sering kamu sebagai ketua merasa khawatir } \\
\text { tidak dapat menyelesaikan tugas ekstrakurikuler }\end{array}$ & & & & & \\
\hline 5 & $\begin{array}{l}\text { Pada satu bulan terakhir, seberapa sering kamu sebagai ketua menghindar dari } \\
\text { masalah ekstrakurikuler yang tidak dapat dikendalikan }\end{array}$ & & & & & \\
\hline 6 & $\begin{array}{l}\text { Pada satu bulan terakhir, seberapa sering kamu murung selama menjadi ketua } \\
\text { ekstrakurikuler }\end{array}$ & & & & & \\
\hline 7 & $\begin{array}{l}\text { Pada satu bulan terakhir, seberapa sering kamu mengalami kesulitan } \\
\text { berkonsentrasi selama menjadi ketua ekstrakurikuler. }\end{array}$ & & & & & \\
\hline
\end{tabular}

